\title{
水溶性絹フィブロインを用いた綿の加工
}

\author{
東京都立䄉維工業試験場 河原 豊・古田博一 \\ 東京工業大学工学部 塩谷正俊
}

\section{Modification of Cotton Fabrics with Water Soluble Silk Fibroin}

\section{Yutaka Kawahara, Hirokazu Furuta, and Masatoshi Shioya*'}

Tokyo Metropolitan Textile Research Institute, 3-15-5 Honjo, Sumida-ku, Tokyo, 130 Japan

* Department of Organic and Polymeric Materials, Tokyo Institute of Technology, O-okayama, Meguro-ku, Tokyo, 152 Japan

\begin{abstract}
Cotton fabrics were treated with a mixture of water soluble silk fibroin and 1,2,3,4 butanetetracarboxylic acid and a mixture of water soluble silk fibroin and urethane resin. The crease recoverability. water absorption and photoyellowing behavior due to ultraviolet irradiation were investigated for treated fabrics. The crease recovery of the fabrics was enhanced and the water absorption was reduced by the treatment with the mixture of water soluble silk fibroin and 1,2,3,4-butanetetracarboxylic acid suggesting the occurrence of crosslinking between the cotton fibrils. The photoyellowing of silk fibroin was suppressed by the urethane resin.
\end{abstract}

(Received May 21, 1996)

\section{1. 緒言}

綿に防しわ性及び防縮性を付与するための改質加工は， 工業的には主としてグリオキザール系樹脂を用いて行わ れている。しかしここの加工では有害なホルマリンが発 生する欠点があり[1]，より安全な加工方法の開発が求 められている。

水溶性タンパク質を用いる擮維の加工はこれまで䅌 〔2]及び羊毛〔3]等に試みられているが、綿に応用された 報告はない。また，この加工に用いられる水溶性タンパ ク質としてはコラーゲン，ケラチン由来のものが多く, 絹フィプロイン由来のものは殆ど用いられていない。さ らに，水溶性タンパク質を織維に固定するためのバイン ダー樹脂についても十分な検討がなされていない。

ここでは，水溶性タンパク質として絹フイブロインを 用い，バインダー樹脂としてホルマリンを遊離しないブ タンテトラカルボン酸及びウレタン樹脂を用い, 䄸の改 質加工を試みた。

\section{2. 実殹}

\section{1 試料}

綿布（かなさん 3 号, JIS L 0803）を温湯で洗净した のち実験に供した。水溶性絹フィブロインは市販品（ア イエス興製, ミクロシルクA-32S, 分子量50,00070 ,000）を用いた。バインター樹脂は，1，2，3、4-ブタン テトラカルボン酸 (東京化成製、試薬) 及び市販の熟反 応型ウレタン樹脂（第一工業製薬製，エラストロンMF9, 有効成分 $31 \%$ ，イソプロパノール（安定剂）19\%）を用 いた。ブタンテトラカルボン酸の触媒として次亜リン酸 ナトリウム, ウレタン樹脂の触媒としてジラウリン酸ジ ーnーブチルスズ（N）（第一工業製薬製，Cat. 64 ，有効 成分 $14 \%$ ）(以下ラウリルスズ）を用いた。

\section{2 化学加工}

1.2,3,4-ブタンテトラカルボン酸 $10 \% / \mathrm{NaH}_{2} \mathrm{PO}_{2}$ $5.5 \%$ の水溶液とウレタン樹脂 $10 \% /$ ラウリルスズ $0.5 \%$ の水溶液に各々 $0 ー 5 \%$ 䅌フィブロインを溶解して加工 浴を調製した。綿布を加工浴に浸漬 (空温) した後, 溶 液による重量增加率が100\%になるように控液して，予 備乾燥 (80C，20分間) した後，ブタンテトラカルボン 
酸を用いたときは $170^{\circ} \mathrm{C}$ ，ウレタン樹脂のときは $150^{\circ} \mathrm{C} に$ おいて熟処理（各5 分間）した。さらに，蒸留水で募沸 (15分間) して未反応物を除去し，付着率を加工前後の 畭燥重量の変化から求めた。

\section{$2.3 \mathrm{X}$ 楾回折}

口-夕式X線回折装置（RINT2400，理学電機製）及 びイメージングプレート（R-AXIS DS3，理学電機製） を用いて，グラファイトで単色化した CuK a 線による 広角 $X$ 線回折測定を行った。回折強度分布から結晶化度 をピーク分離法によって求めた。

\section{4 黄变性試碒}

綿布にカーボンアーク灯光（スガ試験機製，フェード メーターFAL-AUHB型）による紫外線を155時問照射し た後，分光反射率を測定して（Kollmogen 社製，マクヘ ス CE7000).JIS 2 8715により白色度指数を求めた。分 光反射率の測定は, JIS-D 65 光源, $10^{\circ}$ 視野で行った。

\section{5 しか回復性試鋻}

JIS L 1059モンサント法によって標染（20，65\% RH）及び湿潤状態での加工布のたて亲及びよこ糸方向 のしわ角を測定し，その合計值からしわ回復性を評価し た。

\section{6 吸水性試験}

JIS L 1096によって測定した。

\section{3. 䊅果と考察}

図 1 に付着率の加工浴中の絹フィブロイン蕽度に対す る依存性を示す。いずれのバインダー樹脂（ブタンテト ラカルボン酸（以下 BTCA），ウレタン樹脂（以下

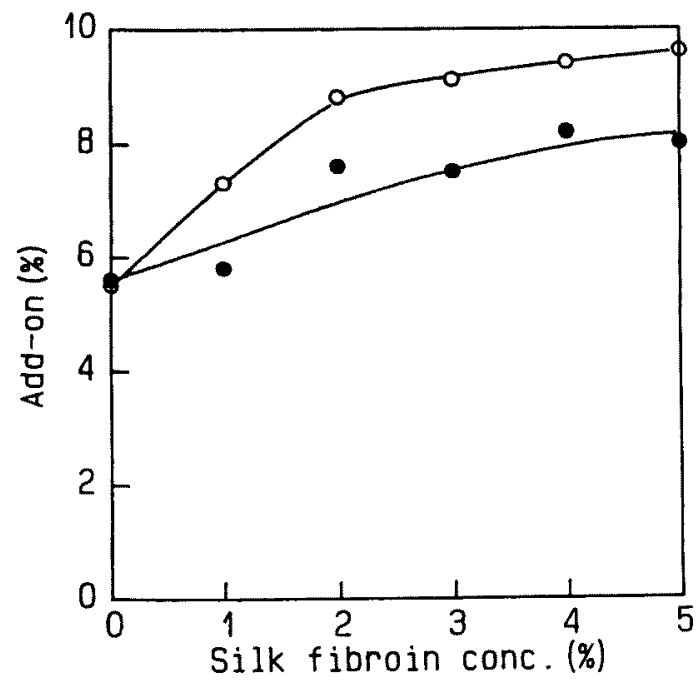

Fig. 1 Plots of add-ons against silk fibroin concentra. tions: (O) BTCA; (O) MF9.
MF9)）を用いても組フィブロイン濃度の增加とともに 付着率が增加した。BTCAの方が付着率が高くバインタ 一樹脂としての効果が優れている。图 2 に加工布の走查 型電子顕微鏡写真を示す。絹フィプロイン濃度が高くな ると，MF9の方が BTCAに比べて加工戍が轿維表面に 析出しやすいことがわかる（图 $2 \mathrm{f}$ )。

絹を有機溶媒に浸漬すると溶媒結晶化を生じる[4]。 MF9には安定㓲としてイソプロパノールが含まれている。 絹フィブロインをイソプロパノール20\%水溶液に溶解さ せ10\%の溶液とし，20時間室温に放置したところゲルが 生じた。ゲルを乾燥させた後, 広角X線回折強度分布を 測定した結果，綃フィブロインの非晶性の散乱強度曲線 (図3 a ) がゲル化によって結晶性のピークに変化した ことから（図 $3 \mathrm{~b} ）$ ，䅌フィブロインが溶媒結晶化した ことがわかる。ピーク分離法によってゲル化した縝フィ ブロインの結晶化度を求めたところ $22.9 \%$ であった。 MF9を用いた場合の加工殽の析出は，綟フィブロインが イソプロパノールによって溶媒結晶化し，挠維表面で疑 固するためと考えられる。

䅌は紫外線によって黄变する性質を有する。絹フィブ ロインの付着は加工布の紫外線による黄変を促進する恐 れがある。加工布に155時間紫外線を照射したのち，白 色度指数を測定した（表 1 )。BTCA では絹フィブロイ ン濃度が高くなると白色度指数が著しく低下した。一方， MF9では絠フィプロイン濃度が高いときにおいても白色 度指数は未加工と同程度であった。程フィブロインの黄 变が抑えられたのはウレタン樹脂が絹の黄变の原因とな

Table 1 Characteristics of Treated Cotton Fabrics

\begin{tabular}{cccccc}
\hline \multirow{2}{*}{ Resin } & $\begin{array}{c}\text { Silk } \\
\text { conc. }\end{array}$ & $\begin{array}{c}\text { Whiteness } \\
\text { index }\end{array}$ & \multicolumn{2}{c}{$\begin{array}{c}\text { Crease angle } \\
\left({ }^{\circ}\right)\end{array}$} & $\begin{array}{c}\text { Water } \\
\text { absorption }\end{array}$ \\
\cline { 4 - 5 } & $(\%)$ & & Standard & Wet & $(\%)$ \\
\hline Untreated & 0 & 75.3 & 174 & 159 & 74.4 \\
\hline BTCA & 0 & 72.0 & 285 & 275 & 60.7 \\
& 1 & 69.7 & 292 & 290 & 59.0 \\
& 2 & 65.0 & 297 & 296 & 57.5 \\
& 3 & 61.7 & 274 & 284 & 55.6 \\
& 4 & 59.3 & 271 & 282 & 59.1 \\
& 5 & 56.5 & 250 & 288 & 60.7 \\
MF9 & 0 & 77.6 & 219 & 249 & 62.6 \\
& 1 & 77.5 & 216 & 236 & 63.7 \\
& 2 & 77.4 & 222 & 248 & 65.2 \\
& 3 & 75.4 & 213 & 243 & 62.6 \\
& 4 & 75.7 & 205 & 246 & 65.0 \\
& 5 & 74.5 & 194 & 257 & 64.0 \\
\hline
\end{tabular}



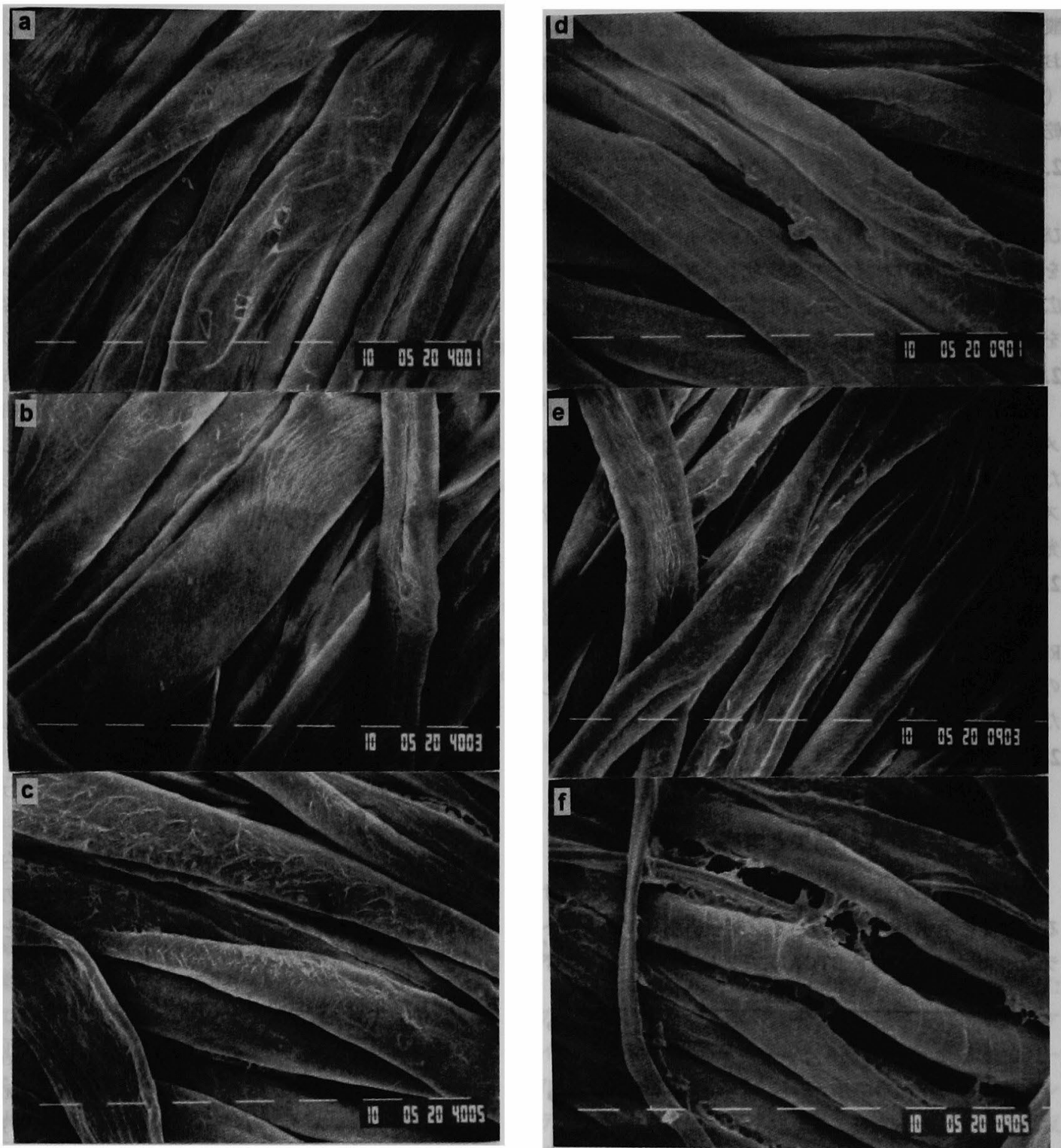

Fig. 2 Scanning electron micrographs of cotton fabrics treated with a mixture of BTCA and (a) 1, (b) 3, and (c) $5 \%$ silk fibroin, and a mixture of MF9 and (d) 1 , (e) 3 , and (f) $5 \%$ silk fibroin. Scales correspond to $10 \mu \mathrm{m}$.

るトリプトファンなどに度応して [5-7]，柴外線の照射 によるラジカルなどの発生を抑えたためと考えられる。 加工布のしわ回復性の測定結果も表 1 に示した。標準 及び湿潤のいずれの状態においてもしわ回復角度が未加 工に比べて増加し, その増加の程度はBTCAを用いた ときの方が顕著である。絹フィブロイン濃度依存性につ いては, BTCA では絹フィブロイン $2 \%$ \%おいてしわ回 復角度が最大值を示したが, MF9では絹フィブロインの 濃度を増加しても, しわ回復角度はMF9 単独で加工し
たときと同程度であった。

加工布の吸水率の測定結果も表 1 に示した。いずれの バインダー樹脂で加工を行っても吸水率が未処理に比べ て減少し，その減少の程度はBTCAの方が著しい。ま た，BTCA では吸水率が絹フィブロイン濃度 $3 \%$ におい て最小となるが, MF9でほ絹フィブロイン濃度が増加し ても吸水率はMF9 単独で加工したときと同程度であっ た。

しわ回復性能の向上と吸水性の低下は, 繊維のフィブ 


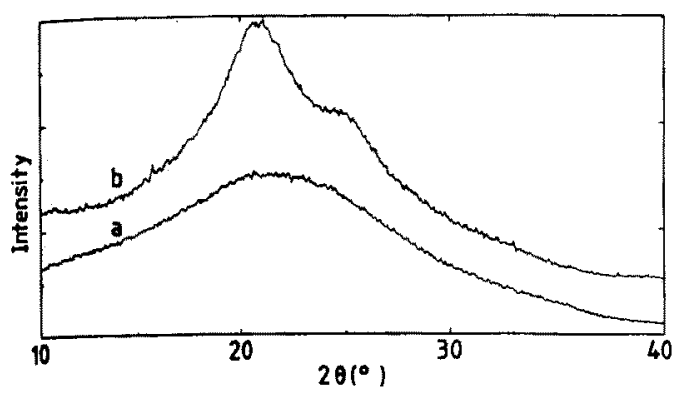

Fig. 3 Wide-angle $X$-ray scattering intensity distributions of silk fibroin: (a) silk fibroin, (b) silk fibroin tre ated with isopropanol.

リル間に加工唷による架橋結合が生成したことを示唆す る[8]。BTCAでは MF9に比べてそれらの値の变化が大 きく，BTCA は MF9 に比へて架橋作用が強いと考えら れる。また，BTCA ではそれらの値の変化が組フィブロ イン瀑度に依存したことから，粗フイブロインはBTCA による架棉結合の生成を促進すると考えられる。 BTCA で綿の加工を行うと，引製強さが低下しやすい ことが報告されている[9]。また，BTCAには絹フィブ ロインの黄変を揤制する効果がない。しかし，MF9には 黄変防止作用と鐵維間の摩擦を低下させ引裂先端部への
応力集中を緩和して引裂強さを向上させる効果がある (9.10)。MF9をBTCA と併用して加工を行うことで，黄 変を防止し，引裂強さの低下を補うことが可能と考えら れる。

\section{文献}

1. J. D. Reid, R. M. H. Kullman, and R. M. Reinhardt. Text. Chem. Color., 3, 72 (1971)

2、水島慗三郎，小杉 宏，特開昭 54-30955（1979）.

3. 北野道雄，染色工業，43，180（1995）.

4. 河原 豊, 䄉学誌, 50, 43 (1994)

5. 風本 奖, 今井其枝, 䄳学誌, 13，139（1957）,

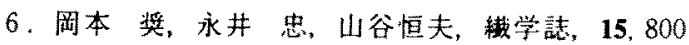
(1959)

7. Y. Kawahara, M. Shioya, T. Kikutani, and A. Takaku, Am. Dyest. Rep., 83 (10), 28 (1994).

8. Y. Kawahara, H. Furuta, M. Shioya, T. Kikutani, and A. Takaku. Sen'i Gakkaishi, 50, 505 (1994).

9. 細谷千明, 古田博一, 杉山満雄、嬂維加工，45, 451 (1993).

10. Y. Kawahara, M. Shioya, and A. Takaku. Am. Dyest. Rep. 84 (8), 36 (1995). 